ІНФОРМАЦІЙНИЙ ТЕРОРИЗМ: ДЖЕРЕЛА ФОРМУВАННЯ ТА АКТИВІЗАЦІї В УКРАЇНІ

\title{
INFORMATION TERRORISM: SOURCES OF FORMATION AND ACTIVATION IN UKRAINE
}

\begin{abstract}
у статті висвітлено питання джерел формування та активізації інфрормаційного тероризму в Україні. На основі аналізу змісту інформаційно-комунікативної діяльності, методів та способів ї̈ ведення різними іноземними та вітчизняними ЗМІ в українському інфоормаційному просторі та поза його межами показано, що основними чинниками формування й поширення інформаційного тероризму в Україні є процеси комерціалізації ЗМІ та їх перегони за сенсаційністю повідомлення незалежно від характеру інфрормації; доступність мережі Інтернет і відсутність належного контролю за змістом поширюваної інсрормації, що є загрозою для інфрормаційної безпеки країни; особливості покриття українським контентом інфрормаційного простору України, що сприяє перетворенню частини населення країни на цільову авдиторію дезінформації; риторика радикально налаштованих осіб, яку використовують інфрормаційні служби поза межами країни задля поширення недостовірної інсормації про загальні суспільні настрої людей; інсрормаційна агресія Росії проти України, яка використовує сучасні інструменти впливу на свідомість людей; перенасиченість українських ЗМІ повідомленнями, що висвітлюють акти насильства; численна авдиторія для обговорень актів насильства в соціальних мережах, що сприяє їх тиражуванню і поширенню; візуалізація актів терористичної діяльності в сочіальних мережах, метою якої є представлення суб'єктів цієї діяльності як героїв, визволителів та борців за справедливість; можливість здійснення інформаційних атак щодо української інфрормаційноі системи в організаційно-комунікаційних цілях через їх слабку захищеність. Показано, що інформаційний тероризм в українському інсрормаційному просторі має на меті формування суспільної напруги, панічних настроїв та хаосу, метою яких $є$ маніпулювання свідомістю людей і тиск на прийняття вигідного для суб'єкта впливу рішення державними структурами.
\end{abstract}

Ключові слова: інорормація, тероризм, інфрормаційний тероризм, джерела інфрормаційного тероризму, інформаційний вплив, інфрормаційна агресія, медіатероризм, кібертероризм.

The article covers the issues of sources of formation and intensification of information terrorism in Ukraine. Based on the analysis of the content of information and communication activities, methods and ways of conducting it by various foreign and domestic media in the Ukrainian information space and abroad, it is shown that the main factors in the formation and spread of information terrorism in Ukraine are media commercialization and clickbait of the news regardless of the nature of the information; easy access to the Internet and lack of proper control over the content of the information, which poses a threat to the information security of the country; features of Ukrainian content coverage in the information environment of Ukraine, which allows to turn part of the country's population into a target audience of misinformation; the rhetoric of radicals, which is used by mass media outside the country in order to spread unreliable information about the general social mood of people; Russia's information aggression against Ukraine, which uses modern tools to influence people's minds; Ukrainian media flooded with reports covering acts of violence; a large audience for discussions of acts of violence on social networks, which contributes to the increase and spread of violence; visualization of acts of terrorist activity in social networks, the purpose of which is to present the subjects of this activity as heroes, liberators and fighters for justice; the possibility of information attacks on the Ukrainian information system for organizational and communication purposes due to their weak security, etc. It is shown that information terrorism in the Ukrainian mass media aims to create social tension, panic and chaos, the purpose of which is to manipulate the minds of people and pressure to make decisions beneficial to the subject of influence by government agencies. Key words: information, terrorism, information terrorism, sources of information terrorism, information influence, information aggression, media terrorism, cyberterrorism.
Постановка проблеми. Сучасні суспільні реалії свідчать про створення глобальної інформаційної інфраструктури, яка чинить інформаційний вплив на думки мільйонів людей. Серед цієї інформації особливе занепокоєння викликає потік новинних подій, рекламних роликів, фільмів і програм, зміст і поширення яких $є$ формою насильства над свідомістю людей. Основним наслідком цього інформаційного насилля $€$ впровадження в суспільну свідомість ідей, які посилюють суспільну напругу, стимулюють хаос і страх та підривають довіру до діяльності влади. Такий інформаційний вплив на свідомість людини має ознаки терористичної діяльності і являє собою сьогодні нову форму, а саме інформаційний тероризм. За останні роки методи й засоби цієї нової форми тероризму еволюціонували настільки, що перетворили його на одну з найсерйозніших загроз як для окремих держав зокрема, так і для міжнародного співтовариства загалом. Особливе занепокоєння викликає сьогодні активізація інформаційного тероризму в українському 
суспільстві, тому вибрана тема для дослідження є на часі.

Аналіз останніх досліджень і публікацій. Проблематика інформаційного тероризму привертає сьогодні все більшу увагу науковців з огляду на його вплив на свідомість людини та діяльність держави загалом. Незважаючи на численні зарубіжні і вітчизняні дослідження цієї нової форми тероризму, варто відзначити, що в розумінні поняття інформаційного тероризму має місце його змістовна неоднозначність і, відповідно, аналіз його природи. Дослідженню окремих аспектів та видів інформаційного тероризму приділяється увага у наукових розвідках таких зарубіжних та українських учених, як К.С. Герасименко, О.М. Грищенко, О.П. Дзьобань, Г. Крюмель, Волтер Лакер, М. Маклюен, Г. Почепцов, А.В. Федоров, Брюс Хоффман, В.В. Циганов, Алекс Шмід, Т.П. Яцик. Щодо аналізу тенденцій розвитку інформаційного тероризму за умов сучасного українського суспільства, то хотілося б відзначити праці таких дослідників, як М.П. Гетьманчук, К.С. Герасименко, Н.Ф. Семен.

Аналіз наукових джерел і публікацій свідчить про те, що подальших наукових досліджень потребує як смислове та змістовне осмислення цього феномена, так і аналіз джерел його формування в українському суспільстві.

Постановка завдання. Метою статті $€$ дослідження джерел формування й активізації інформаційного тероризму в Україні на основі аналізу змісту інформаційно-комунікативної діяльності, методів та способів її ведення різними іноземними та вітчизняними ЗМІ в українському інформаційному просторі та поза його межами з конкретизацією смислового значення поняття «інформаційний тероризм».

Виклад основного матеріалу дослідження. У контексті смислового і змістовного осмислення поняття «інформаційний тероризм» варто зазначити, що в сучасній науковій літературі у розумінні феномена інформаційного тероризму акцент переважно ставиться на різноманітних формах і методах впливу на інформаційні інфраструктури держави та цілеспрямоване використання цієї інфраструктури для створення умов, які мають катастрофічні наслідки для життєдіяльності суспільства й держави. Наприклад, розуміння інформаційного тероризму як «цілеспрямованого впливу на інформаційну інфраструктуру для створення умов, що тягнуть за собою катастрофічні наслідки для різних сторін життєдіяльності суспільства і держави» має місце в праці В.В. Циганова [17, с. 25].

Доволі часто феномен інформаційного тероризму розглядають у контексті пропаганди та інформаційної війни. Наприклад, вітчизняна дослідниця Тетяна Яцик вважає, що сучасний інформаційний тероризм характеризується як множина інформаційних війн та спецоперацій, пов'язаних із національними або транснаціональними кримінальними структурами та спецслужбами іноземних держав [18, с. 57]. Головною метою інформаційного тероризму, на думку А.В Федорова, $€$ прагнення «до того, щоб терористичний акт мав небезпечні наслідки, став широко відомий населенню і отримав великий суспільний резонанс» [16, с. 94]. Інформаційний тероризм як форму «негативного впливу на особистість, суспільство і державу всіма видами інформації» розуміють М.Ю. Григорьєв та Е.Б. Родюков [7, с. 175]. Заслуговує на увагу позиція вітчизняного науковця К.С. Герасименка, який вважає, що сутність інформаційного тероризму полягає у дестабілізації суспільства, створенні в ньому атмосфери громадянської непокори і недовіри суспільства до дій та намірів влади шляхом організації спеціальних медіакампаній [4].

Наведені вище приклади розуміння сутності інформаційного тероризму дають нам підстави для узагальнення й тлумачення цієї нової форми тероризму як використання інформації та інформаційної інфраструктури задля насильства над свідомістю людей, маніпулювання їх поведінкою за допомогою певних методів і способів впливу, що дає змогу суб'єктам впливу чинити тиск на прийняття вигідних для них рішень з боку держав, груп людей або окремих осіб шляхом створення умов для хаосу, панічних настроїв тощо. Солідарні з позицією В.В. Циганова щодо основних різновидів інформаційного тероризму (інформаційно-психологічний, інформаційно-технічний) з незначним доповненням їх сутності. Під інформаційно-психологічним тероризмом розумітимемо спосіб впливу ЗМІ на свідомість і поводження людей за допомогою інформації, що пропагує насилля або сама є формою насилля. Під інформаційно-технічним тероризмом маємо на увазі спосіб впливу на інформаційне середовище супротивника, сутність якого полягає в завданні збитків окремим елементам або всьому інформаційному простору супротивника задля шантажу та прийняття вигідних для суб'єкта впливу рішень.

Класифікація використовуваних інформаційним тероризмом засобів визначає його основні форми. До різновиду інформаційно-психологічного тероризму віднесемо медіатероризм, а до інформаційно-технічного кібертероризм.

Виходячи з досвіду сучасної практики інформаційного тероризму, можемо стверджувати, що людство сьогодні терпить навалу насамперед візуальної форми медіатероризму. Найбільш привабливим для медіате- 
роризму інформаційним каналом стає «телебачення реального часу». Працюючи в режимі «живого ефіру», телебачення перетворює роз'єднаних простором глядачів на єдиний психологічний натовп, який є не стільки свідком подій, скільки його безпосередньою віртуальною жертвою. Емоційне навантаження від сприйнятого руйнує захисні механізми свідомості, сприяючи полярним змінам психічного стану населення. Чого вартує «торгівля жахами» з різної тематики, якої в українському ефірі доволі багато! Так, зокрема, в телевізійному ефірі України сьогодні засилля телевізійних програм, у яких основною темою $€$ кримінал, наприклад «Свідок», «Надзвичайні новини», «Поліцейська хвиля».

Висвітлення інформації, особливо в режимі реального часу, часто ускладнює роботу журналістів, змушуючи їх імпровізувати і самостійно розбиратися в подіях. Перед ними періодично постає дилема: бути безпристрасним спостерігачем висвітленої події або виступати в ролі співчутливого захисника жертв. Найчастіше журналісти вибирають другий шлях. Виникає парадокс: розкривши перед масовим глядачем свої почуття, що збігаються з почуттями самого глядача, ведучий підсилює неприязнь населення до дієвих осіб сюжетів насильницького характеру, але водночас привертає увагу до події, змушуючи постійно згадувати про неї та обговорювати деталі побаченого. На питання про те, чому така тематика привертає увагу журналістів, відповісти не складає труднощів. Сучасний медіапростір перетворився на медіаринок, де основним товаром є сенсаційна інформація. Саме такий виклад інформації дає змогу триматися «на плаву» і набувати високих рейтингів переглядів. У такий спосіб значна частина мас-медіа не просто активно «торгує страхом», але й значною мірою продукує його. Поширеними прийомами надання такої інформації $€$ аргументація до людини, аргументація до публіки, замовчування, аргумент загрози, аргумент авторитету тощо. Фактологічним забезпеченням аргументів зазвичай слугують статистичні дані, що не підтверджені відповідним джерелом, замовчування об'єктивно наявних даних тощо. Цими особливостями діяльності ЗМІ активно користуються сьогодні різні міжнародні терористичні організації, які намагаються «рекламувати» свою діяльність.

У погоні, власне, за сенсаційністю особливе місце в діяльності ЗМІ сьогодні посідають різні чутки та їх поширення. Найбільшу вагу в рамках медіатероризму мають два їх види, такі як чутки-залякування й агресивні чутки. Чутки-залякування особливого поширення набувають у ситуаціях складних соціальних і політичних реформ, зміни влади або соціально-політичної системи загалом. Їх сюжети варіюються від песимістичних до явно панічних. Найбільш часто трапляються чутки-залякування, засновані на неминучому підвищенні цін на продукти харчування, наближенні голоду, невідворотній економічній або соціальній катастрофі тощо. Як це не парадоксально звучить, але різноманітні програми з політичної тематики на різних телевізійних каналах $€$ джерелом поширення такого штибу чуток. Довіряючи їм, частина населення, наприклад, починає закуповувати різні продукти в нерозумних обсягах, що спотворює кон'юнктуру ринку і призводить до стрімкого зростання цін на товари.

Агресивні чутки, формуючи афективну спільність «ми», яка протистоїть спільності «вони», $€$ прямою провокацією агресивних дій. Нині для України найбільша інформаційна терористична загроза виникає через агресивну політику Російської Федерації, спрямовану на дестабілізацію та дезінтеграцію нашої держави та пов'язану з цим організацію та підтримку сепаратистської і диверсійно-терористичної діяльності. Ця масштабна інформаційна агресія проти української влади здійснюється від подій Майдану 2013-2014 рр. Так, із початком російської агресії Україна перемістилася з 51 на 11 місце серед 163 країн, які внесені до Глобального індексу тероризму в усіх його проявах [2, с. 17]. За даними статистики, на інформаційну війну проти України щорічно Росія витрачає до 4 млрд. доларів [9].

Основними об'єктами деструктивного інформаційного впливу Росії проти України $€$ духовні, культурні, історичні, національні цінності в різних сферах суспільного життя; система формування суспільної свідомості; система формування громадської думки; інформаційні ресурси та структури. Так, ще задовго до анексії Криму РФ використовувала такий маніпулятивний прийом, як переписування історії, який діє завдяки руйнуванню історичної пам'яті. Картина історичної дійсності «стирається» зі свідомості людини шляхом підміни фейковими даними. Ось приклади деяких меседжів, використовуваних російською пропагандою (наводимо мовою оригіналу - Г. П.): «После развала СССР россияне не переставали считать Крым своим»; «Развал СССР превратил фарс в трагедию: сотни тысяч русских жителей полуострова оказались оторваны от своей исторической родины»; «С приходом к власти в республиках националистических правительств русские испытывают все возрастающее давление, проявившееся в различных формах. В данном случае это нарастающий с каждым годом процесс украинизации, который в русском - и в языковом, и в этническом плане - в Крыму проходит наиболее болезненно» [8, с. 11].

Дієвість впливу в інформаційному просторі Криму російських медіа була зумовлена 
достатньо значною часткою російськомовного медіапродукту та недостатньою кількістю якісних кримських ЗМК. Так, у відсотковому співвідношенні друковані ЗМК за мовою видання мали такі показники: $72 \%$ - російські, 17\% українські, 8\% - кримськотатарські, по 1\% англійські, німецькі, грецькі [8, с. 5].

Російські медіа пильно моніторять слабкі сторони в українській політиці і щоразу змінюють свої меседжі. Якщо на початку російської військової агресії проти України інформаційна війна була спрямована на популяризацію «русского мира», заперечення цілісності української держави, переписування історії українського народу, то нині тактика впливу спрямована на роз'єднання суспільства. Зазвичай такий інформаційний вплив ґрунтується на використанні критичних висловів деяких радикально налаштованих українських політиків, псевдоукраїнських патріотів тощо. До числа таких висловлювань можна віднести таке (наводимо мовою оригіналу - Г. П.): «злость, агрессия, ненависть и нетерпимость возводятся в ранг национальной идеи», озвучене В.В. Медведчуком у відповідь на «вандалізм» з банером його дружини [3].

Активно використовуються російською стороною такі форми дезінформації, як термінологічне «мінування», тобто викривлення первинної сутності принципово важливих, базових термінів і тлумачень; тенденційне, упереджене викладення фактів або іншої інформації щодо подій; «чорне» дезінформування, яке передбачає використання неправдивої інформації [12, с. 125]. Зокрема, Міжнародна місія Світового конгресу українців зі спостереження за парламентськими виборами 2019 р. в Україні зафіксувала численні приклади російської дезінформації про Україну та її виборчі процеси в іноземних медіа. Зокрема, 4 липня 2019 р. на сайті "AgoraVox" було опубліковано статтю французькою мовою «Розпад влади в Україні розпочався», основними меседжами якої є такі: «Девальвація президентської влади ще більше прискорює дезінтеграцію української держави», «Україна, яка раніше не мала суверенітету, тепер відкрито перетворюється на розмиту територію, чия політика задається зовнішніми акторами, і саме вони визначають, розпочинати дезінтеграцію України чи ні» [10]. 22 липня 2019 р. новинний вебсайт "Regnum" опублікував статтю російською мовою під назвою «Вибори до Ради були названі найбільш закритими в історії». У статті цитується один із російських чиновників, який сказав: «Судячи з кількості порушень процедури, 21 липня не можна назвати виборами» [10].

Особливе місце в дезінформації про українську політику має тема статусу української мови в нашій державі з відповідними заголовками публікацій, такими як «Украина, новые языковые проблемы: похищение будущего». Зокрема, у статті на сайті «РИА Новости Украина» зазначено таке (наводимо мовою оригіналу - Г. П.): «Из-за принятого Верховной Радой нового закона об образовании миллионы граждан Украины будут дискриминированы в праве учиться и учить своих детей на родном языке» [15]. У цьому контексті логічним є запитання до російської влади щодо кількості україномовних шкіл у Росії та забезпечення прав українців навчатися рідною мовою в цій країні.

Як інформаційну зброю Росія сьогодні використовує стандартні рекламні інструменти, типові для багатьох глобальних онлайн-соцмереж, за допомогою яких можна промоціювати пости та публікації, акаунти або тематичну сторінку; створювати та спрямовувати трафік користувачів на вебсайт; промоціювати заходи; здійснюваи таргетинг, який дає можливість виокремити з наявної авдиторії лише ту її частину, яка відповідає потрібним критеріям, і спрямувати на неї рекламне повідомлення. Наприклад, російські силові відомства використовували систему «Диспут», яка відстежує поширення інформації в блогосфері, зокрема виявляє популярні записи та авторів. Система «Монітор-3» має на меті збирати дані для OSINT-розвідки, а система «Шторм-12»сприяти поширенню інформації та впливати на суспільну думку. У 2013 р. в РФ була створена організація для впливу на суспільну думку, яка стала широко відомою як «тролі з Ольгіна». Навіть через два роки після початку війни, у 2016 р., була виявлена мережа ботів у соцмережах, які поширювали в Інтернеті заклики до насилля проти української влади та заклики виходити на «Третій Майдан» [13].

Звичайно, центральною темою російської пропаганди є тема подій в АТО. Так, спільнота мережевого інформаційного агентства з чітко вираженою пропутінською позицією «ANNA-News|Фронтовые новости|Сирия|ЛНР| ДНР| » нав'язує читачеві такі стереотипи про ці події: «українська влада веде брудну боротьбу проти народу»; «українська армія обстрілює мирне населення на території Донецької та Луганської областей» [14, с. 129]. Проаналізувавши його трафік, Н.Ф. Семен стверджує, що число користувачів цього мережевого інформаційного агентства сягає понад 800 тисяч за місяць [14, с. 129].

Особливої ваги сьогодні набувають так звані атакуючі мережеві проєкти онлайн-формату, орієнтовані на цільові групи, що підходять під категорії своїх та нейтральних. Метою цих проєктів є внесення ґрунтовних та легких психологічних установок на підсвідомому рівні. Такі проєкти допомагають у реалізації стратегій, спрямованих на формування невдоволення, залякування, дії протесту. 
Захисні мережеві проєкти зазвичай використовуються для створення ментального бар'єру у свідомості «своїх» цільових груп або здійснення впливу на представників цільових груп, що не визначилися. Це проєкти, що містять інформацію у вигляді прямих звинувачень, викриття, пошуку винних. Прикладами $\epsilon$ «Агентство интернет-исследований», «Антимайдан», «Ватник», «Интернет-ополчение», «Информационный солдат Донбасса», «Кибер беркут», «Русская весна», які використовує російська сторона в інформаційній війні проти України. Базовими інструментами просування їх контенту у соціальній мережі $€$ пост, подія, коментар. Щодо прийомів та засобів просування контенту в соцмережах, то вони доволі варіативні та залежать від характеру ситуації, постановки завдання та комунікаційних можливостей системи (просування відео, фото, аудіоконтенту, створення та поширення мемів, вірусного контенту тощо).

Головною новинкою інформаційної війни Росії проти України вітчизняний науковець М.П. Гетьманчук називає «роботу з віртуальними об'єктами» [6, с. 302]. Слід назвати такий віртуальний об'єкт, як «Новоросія», метою якого була дестабілізація всього південного сходу України. Проте цей проєкт провалився. $\Theta$ думки, що проєкт «Новоросія» був «димовою завісою», якою Росія намагалася прикрити анексію Криму [11].

Зіставляючи діяльність 3МІ Росії та України в умовах «гібридної війни», можемо розмежувати низку принципових відмінностей базового, комунікативного та організаційного рівнів. На відміну від України, Росія має єдині центри прийняття рішень і добре вибудувану вертикаль управління федеральними каналами, а також досвід управління в кризових ситуаціях. Наприклад, вона проводить конференції з теми інформаційних воєн, протидії «кольоровим» революціям. Крім того, доктрина «русского мира» налаштована на підтримку російськомовного населення за межами Росії, наприклад у Донецькій та Луганській областях. Найвідомішою пропагандою останніх років $є$ розвінчання тези про українців як про братній народ, виключивши 3 дружніх «бандерівців», «хунту», «фашистів». На основі цього поділу була побудована політика легітимації нової влади в Криму й правильність дій тих, хто воює на боці проросійських сил у Донецьку та Луганську. Варто зауважити, що після анексії Криму Росія почала вести політику тотальної зачистки кримського інформаційного простору від українських мас-медіа. Так, наприклад, після анексії перестала мовити в Криму ТОВ «Чорноморська ТРК», згодом репресій зазнав кримсько-татарський канал ATR. Журналісти цих телеканалів змушені були переїхати і відновити роботу в Києві. Сьогодні на півострові не залишилося жодного українського мас-медіа, яке б могло об'єктивно розповідати про події в Україні [1, с. 7].

На територіях, підконтрольних бойовикам так званих ЛНР та ДНР, також закрилася низка медіа через фізичну загрозу життю журналістів цих редакцій. Натомість на цих територіях бойовики почали створювати свої медіа, зокрема телеканал «Луганськ 24», агентство «Новоросія». Ця ситуація дала поштовх для створення та розвитку нових медіа-ініціатив, спрямованих на інформування жителів східних регіонів України, зокрема найвідоміших, таких як програми «Донбас. Реалії» (виходить на радіо «Свобода»), «Громадське телебачення Донбасу», сайт «Четвертая власть» (vlada.io)» $[1$, c. 8]. Проте таких заходів недостатньо. Переважання на цих територіях впливу російських медіа дає змогу проводити потужну дезінформацію населення про події в Україні. Наприклад, російські телеканали ілюстрували ситуацію, що склалася у Сімферополі, кадрами протистоянь з Євромайданом; повідомляли про великі черги українських біженців, які стояли біля російського кордону, публікуючи фото з пропускного пункту «Шегині»; оприлюднювали неправдиву інформацію про перехід українських військових на бік Росії.

Населення окупованих територій, яке споживало такого штибу інформацію, виявилося чутливим до впливів меседжів російської пропаганди. Так, за даними соціологічного опитування 2015 р., 49\% назвали Майдан «фашистським переворотом», а 67\% вбачали його причиною олігархічну змову та маніпуляції США [1, с. 9].

Проведений аналіз дає підстави стверджувати, що помилки інформаційної політики України створили основу для російської інформаційної агресії на не підконтрольних сьогодні українській владі територіях Донецької і Луганської областей та мали наслідком збройний конфлікт. Хоча як інструмент здійснення відповіді на російську інформаційну агресію було створено низку урядових і неурядових проєктів, таких як «нфформаційні війська України», "StopFAKE", «нформспротив» та канал іномовлення, спрямований на закордонну аудиторію "Ukraine Today", проте нині їхня діяльність потребує більш системного підходу до аналізу російської антиукраїнської дезінформації та протидії їй.

Розкриваючи механізм формування інформаційного тероризму в українському суспільстві, маємо також наголосити на доступності нині Інтернету для реклами своєї діяльності різноманітними міжнародними терористичними організаціями. Здебільшого пропаганда радикальних ідей відбувається в популярних соціальних мережах "Facebook", «ВКонтакте», "Twitter", "Youtube”. Задля цього використову- 
ються такі поширені форми пропагандистських матеріалів, як мультфільми або комп'ютерні ігри, основним сюжетом яких $є$ прославляння терористичних актів, місії терористів-смертників, безбідне життя терористів. Так, наприклад, задля пропаганди пропалестинських і антиізраїльських поглядів Хесболлах використовувала такі саморобні відеоігри, як "Special Force" i "Under Ash". У вересні 2012 р. Міноборони Австралії випустило звіт, у якому розповідалося про те, що члени руху «Талібан» створюють у "Facebook" фейкові сторінки з фотографіями привабливих жінок. За їх допомогою ісламісти вивідують у солдатів інформацію [13]. До цього додаємо, що лише у 2016 р. Служба безпеки України попередила вчинення 30 терористичних актів, затримала 56 учасників терористичних та диверсійно-розвідувальних груп [2, с. 19].

Поширеними способами і методами терористичної діяльності є заміна інформаційного змісту сайтів, виведення з ладу або зниження ефективності функціонування структурних елементів інформаційно-телекомунікаційних систем шляхом застосування спеціальних програмних та апаратно-програмних засобів на основі програмного коду, різні форми «віртуальної блокади», семантичні атаки.

Новітні технології значно видозмінили практику кібертероризму загалом. Так, у листопаді 2016 р. відбулося зараження комп'ютерної мережі «Укртелеком» вірусом “Nimda”, який спричинив тимчасове відключення комп'ютерів від мережі Інтернет, а поштовий комп'ютерний вірус "SirCam" «викрадав» документи з органів державної влади [5]. Загалом нині діяльність кібертероризму базується на використанні таких інструментів, як хакерство, вірусні програми, комп'ютерний хробак ("Worm"). Деякі хакерські угруповання ставлять за мету видобування конфіденційної інформації і розкриття її шляхом розміщення в Інтернеті у вільному доступі. Як правило, йдеться про викриття таємних операцій, змов, корупції та інших дій на рівні урядів чи окремих політичних сил.

Уся ця діяльність потребує фінансової підтримки. Відомі факти, що через рахунки у системі "РауPal" на користь «ДНР» та «ЛНР» за місяць переводили понад мільйон доларів [2, с. 32].

Серед форм психологічного впливу активно використовуються такі, як доведення до об'єкта даних про реальні чи ненаявні загрози; прогнози щодо переслідувань, репресій та убивств; шантажування; здійснення вибухів, масових отруєнь, підпалів, захоплення заручників. Одним із найбільш поширених прийомів здійснення психологічного тиску став так званий телефонний тероризм, тобто дзвінки з інформацією про мінування місць масового скупчення людей. Останнім часом повідомлення про нібито мінування публічних місць почастішали в Україні.

Таким чином, можна констатувати, що сучасний інформаційній тероризм в Україні застосовує практично весь арсенал впливу на свідомість людей, наслідком якого є завдання створення труднощів у внутрішньому розвитку українського суспільства й зовнішній діяльності держави, деморалізація свідомості великого числа людей задля формування потрібних для суб'єктів впливу зразків і форм поведінки.

Висновки 3 проведеного дослідження. Інформаційний тероризм як явище нині являє собою серйозну загрозу безпеці для окремої особистості зокрема та держави загалом, позаяк спрямований на повну або часткову деморалізацію об'єкта впливу та дестабілізацію роботи національних інформаційних структур у сучасному інформаційному просторі.

Формуванню й активізації інформаційного тероризму на теренах України сприяють багато внутрішніх і зовнішніх соціальних, політичних, економічних та інших чинників. Аналіз інформаційно-комунікативної діяльності вітчизняних $3 \mathrm{MI}$ та глобальної мережі Інтернет дає нам змогу основними джерелами формування та активізації інформаційного тероризму у вітчизняному медіапросторі назвати перехід ЗМІ на комерційну основу діяльності, яка мотивує до поширення інформації, що має ознаки сенсаційності, незалежно від її характеру; активне використання мережі Інтернет організаціями, чиєю метою $є$ розширення власного інформаційного впливу на свідомість і дії людей та завдання шкоди діяльності національній інформаційній інфраструктурі як інструменту втручання у внутрішні справи держави, метою якого $є$ тиск на прийняття вигідного для суб'єкта впливу рішення; нерівномірність покриття українським контентом медіапростору України, що дає змогу перетворювати населення, не охоплене національним мовленням, на цільову авдиторію дезінформації; війна на Сході України, що активізувала різні форми інформаційного впливу Росії проти України; радикальні настрої частини політиків і населення, що незадоволені діяльністю і політикою влади.

Проведений аналіз джерел формування й активізації інформаційного тероризму за сучасних умов в Україні показав, що подальшого дослідження потребують питання можливих наслідків впливу контенту інформаційного тероризму на процеси внутрішньої соціально-політичної інтеграції. Саме в цьому напрямі варто зосередити наші подальші дослідницькі зусилля. 


\section{ЛІТЕРАТУРА:}

1. Академії української преси. URL: https://www. kas.de/c/document_library/get_file?uuid=c5b9fe7e4dbe-a4a4-68ab-c36aeef06ce5\&groupld=252038 (дата звернення: 3.12.20).

2. Резнікова О.О., Місюра А.О., Дрьомов С.В., Войтовський К.Є. Актуальні питання протидії тероризму у світі та в Україні : аналітична доповідь. Київ : НІСД, 2017. 60 C.

3. Виктор Медведчук прокомментировал поджог баннера с Оксаной Марченко. URL: https://politeka.net/ news/540450-viktor-medvedchuk-prokommentirovalpodzhog-bannera-s-oksanoj-marchenko (дата звернення: 20.11.2020).

4. Герасименко К.С. Сучасні ознаки загроз «інфрормаційного тероризму». Форум права. 2009. № 3. C. 162-166.

5. Геращенко О.С. Кібертероризм як фрактор загрози національній безпеці України: генеза поняття та шляхи протидії. Південноукраїнський правничий часопис. 2016. № 3-4. С. 39-42.

6. Гетьманчук М.П. Гібридна війна Росії проти України: інформаційний аспект. Військово-науковий вісник. 2017. Вип. 27. С. 296-307.

7. Григорьев Н.Ю., Родюков Э.Б. Информационный терроризм. Вестник Университета. 2015. № 5. С. 175-180.

8. Інфрормаційні виклики гібридної війни: контент, канали, механізми протидії : аналітична доповідь / за заг. ред. А.В. Баровської. Київ : НІСД, 2016. 109 с.

9. Малик Я.Й. Інформаційна війна і Україна. Демократичне врядування. 2015. Вип. 15. URL:
http://nbuv.gov.ua/UJRN/DeVr_2015_15_3 (дата звернення: 22.12.2020).

10. Місія СКУ зафріксувала приклади російської дезінсрормації про вибори в Україні в іноземних медіа. URL: https://www.radiosvoboda.org/a/30076464.html.

11. Огляд «Проєкт Новоросія»-game over?». URL: https://www.bbc.com/ukrainian/politics/2015/06/150603_ dnr_over_rl (дата звернення: 10.01.21).

12. Петрик В.М. Сутність інформаційної безпеки держави, суспільства та особи. Юридичний журнал. 2009. № 5. С. 122-134.

13. Рудник Л.І. Соціальні мережі як засіб здійснення терористичних актів. URL: https://goal-int.org/ socialni-merezhi-yak-zasib-zdijsnennya-teroristichnixaktiv (дата звернення: 12.11.2020).

14. Семен Н.Ф. Соціальні мережі як один 3 найефективніших засобів протидії інформаційній агреciї в українському інтернет-просторі. URL: http:// ena.lp.edu.ua:8080/xmlui/handle/ntb/43011.

15. Украина, новые языковые проблемы: похищение будущего. URL: https://rian.com.ua/analytics/ 20170914/1027672095.html (дата звернення: 5.11.2020).

16. Федоров А.В. Супертерроризм: новый вызов нового века. Москва : Права человека, 2002. 392 с.

17. Циганов В.В. Медиа-терроризм. Терроризм и средства массовой инсормации. Киев : Ника-Центр, 2004. 124 C.

18. Яцик Т.П. Особливості інформаційного тероризму як одного із способів інформаційної війни. Науковий вісник Національного університету державної податкової служби України (економіка, право). 2014. № 2. С. 55-60. 